\title{
Prevalence of hepatitis B and $C$ virus co-infection in HIV positive patients attending a health institution in southeast Nigeria
}

\author{
Ifeyinwa Dorothy Nnakenyi ${ }^{1,2}$, Chisom Uchechukwu ${ }^{1}$, Uloaku Nto-ezimah ${ }^{1}$
}

1. University of Nigeria Nsukka, Department of Chemical Pathology.

2. University of Nigeria Teaching Hospital, Department of Chemical Pathology.

\begin{abstract}
Background: The health of people living with HIV/AIDS becomes progressively worse when co-infected with hepatitis $B$ virus (HBV) and hepatitis $\mathrm{C}$ virus (HCV), resulting in shortened life span. The modes of transmission of HIV, HBV and HCV are similar.

Objective: To determine the prevalence of HBV and HCV co-infection in HIV patients.

Method: This was a retrospective study of serology test results for hepatitis B surface antigen (HBsAg) and antibodies to HCV (anti-HCV) of HIV positive patients registered from 2008-2013 (6years) at the University of Nigeria Teaching Hospital. Adult patients with confirmed HIV seropositivity were included. Ethical approval was obtained and confidentiality of the patient information was maintained. Laboratory records were reviewed to obtain $\mathrm{HBs} A g$, anti-HCV, and CD4 T-lymphocyte results. Prevalence was determined by the number of positive results over total number of patients tested. Chi-square test was used to determine relationships and $\mathrm{p}<0.05$ was considered to be statistically significant.

Results: 4663 HIV patient records were included comprising 3024 (65\%) females and 1639 (35\%) males. Serology results showed 365/4663 (7.8\%) tested HBsAg-positive only; 219/4663 (4.7\%) tested anti-HCV-positive only; and 27/4663 (0.58\%) tested both HBsAg and anti-HCV-positive. Correlation of age and sex were statistically significant with HBV and HCV $(\mathrm{p}<0.05)$ but not CD4 count $(\mathrm{p}>0.05)$.

Conclusion: HBV co-infection was more prevalent than HCV, and triple infection was also observed. Screening for these viral infections in the HIV population is necessary for early identification to enable appropriate, holistic management of these patients.

Keywords: Hepatitis B virus; Hepatitis C virus; HIV; co-infection.

DOI: https://doi.org/10.4314/ahs.v20i2.5

Cite as: Nnakenyi ID, Uchechukwn C, Nto-ezimah U. Prevalence of hepatitis B and C virus co-infection in HIV positive patients attending a health institution in southeast Nigeria. Afri Health Sci. 2020; 20(2): 579-586. bttps:// doi.org/ 10.4314/abs.v20i2.5
\end{abstract}

\section{Introduction}

Worldwide, Human immunodeficiency virus (HIV) infection is a serious public health problem and Africa remains the region worst hit by the pandemic with estimated prevalence of 25.7 million people (all ages) living with HIV/AIDS as at 2017. ${ }^{1}$ Available literature suggest that there is faster progression of HIV infection, even to AIDS-defining illnesses in those co-infect-

\section{Corresponding author: \\ Ifeyinwa Dorothy Nnakenyi, \\ University of Nigeria Nsukka, Department \\ of Chemical Pathology; \\ University of Nigeria Teaching Hospital, \\ Department of Chemical Pathology. \\ Email: ifeyinwa.nnakenyi@unn.edu.ng, \\ ifyosegbe@yahoo.com}

ed with either Hepatitis B virus (HBV) and Hepatitis $\mathrm{C}$ virus (HCV). ${ }^{2}$ These worsen patients' prognosis and shorten their life span.

Hepatitis B virus infects liver cells and leads to chronic liver disease such as hepatitis, cirrhosis and hepatocellular carcinoma. According to the 2017 World Health Organization (WHO) Global Hepatitis report, the number of hepatitis B surface antigen ( $\mathrm{HBsAg}$ ) positive individuals in the African region is 60 million, prevalence estimate $6.1 \%, 4.6-8.5 \% .^{3}$ This is estimated to account for 87,890 deaths annually in sub-Saharan Africa. ${ }^{3}$ Similarly, HCV is a major cause of hepatitis with propensity for chronicity. Prevalence data for HCV is limited for most sub-Saharan Africa regions but is estimated at 30 million. ${ }^{4}$

Both viruses have been documented to be more prevalent in HIV positive patients with associated increase
(C) 2020 Nnakenyi ID et al. Licensee African Health Sciences. This is an Open Access article distributed under the terms of the Creative commons Attribution License (https://creativecommons.org/licenses/BY/4.0), which permits unrestricted use, distribution, and reproduction in any medium, provided the original work is properly cited. 
in liver-related morbidity and mortality, which is twice as high in HIV/HBV co-infected individuals than those with $\mathrm{HIV} / \mathrm{HCV}$ co-infection ${ }^{5}$. In sub-Saharan Africa, about 2.6 million people living with HIV are coinfected with HBV and 2.3 million people with $\mathrm{HCV}^{6}$ This may be because HIV, HBV, and HCV share similar routes of transmission enabling co-infection with these viruses. The common transmission routes include parenteral (blood and blood products, unsafe injection practices amongst people who inject drugs, tattooing), and sexual activity (men who have sex with men, heterosexual persons with multiple sex partners).

Studies have shown that HBV and/or HCV co-infection with HIV varies significantly across geographical regions, risk groups and type of exposure involved. Prevalence of $\mathrm{HIV} / \mathrm{HBV}$ and $\mathrm{HIV} / \mathrm{HCV}$ co-infection have been reported in South Africa ${ }^{7}$, Nigeria $^{8}$ and India ${ }^{9}$, the top three countries with the greatest prevalence of people living with HIV. ${ }^{10}$ The WHO recommends that highly active antiretroviral therapy (HAART) should be commenced in HIV patients coinfected with HBV or $\mathrm{HCV}$ irrespective of their CD4 T lymphocyte count ${ }^{11}$, but the choice of regimen depends on which of these viral infections are present or else the patient may be at greater risk for hepatotoxicity.

Likewise, knowing the HBV and HCV status has implications on treatment of those viruses. The WHO global hepatitis strategy to eliminate viral hepatitis as a public health threat by 2030 relies on $80 \%$ of treatment-eligible individuals with HBV and HCV infection being treated ${ }^{12}$, therefore diagnosis needs to be made prior to treatment. Preventive measures include identification of pregnant women who are HBV positive as a pre-requisite for administration of the recommended antiviral drug, to prevent perinatal transmission of $\mathrm{HBV}^{13}$

The framework for action to achieve the set targets of reduction in viral hepatitis in the African region by 2020 includes integration of hepatitis testing into health policies and systems especially among priority populations ${ }^{14}$ such as HIV positive individuals. In obtaining information for focused action, the prevalence of hepatitis coinfection is essential.

In Nigeria, several studies have been done in different geopolitical zones on the prevalence of $\mathrm{HBV}$ and/or HCV co-infection in HIV patients ${ }^{8,15-17}$ but this study will be the first to enroll a large population base as opposed to the smaller sizes of the other studies. Our study was conducted in the south-eastern Nigeria re- gion, which is different from the others, and may expose the differences in prevalence due to religious and sociocultural practices in south-eastern Nigeria, which may contribute to the transmission of the viral infections. This will be important in guiding decisions on which antiviral therapy can be best prescribed in co-infected patients, leading to the appropriate management of HIV and viral hepatitis.

Therefore, we aim to determine the prevalence of hepatitis $\mathrm{B}$ and $\mathrm{C}$ virus co-infection in HIV positive patients attending our health institution in southeast Nigeria.

\section{Methods}

\section{Study design and population}

This was a retrospective study of the HBsAg and anti-HCV results of HIV positive patients enrolled at the HIV outpatient clinic of the University of Nigeria Teaching Hospital (UNTH), Ituku Ozalla, Enugu, southeast Nigeria; which offers free voluntary counseling and testing for HIV. This hospital is a 500-bed tertiary health institution that serves both urban and rural communities. The HIV outpatient clinic had 10,263 newly registered adult patients from 2008 to 2013 with a male: female enrolment ratio of 1:2. Adult male and female patients (aged $\geq 18 \mathrm{yrs}$ ) with confirmed HIV seropositivity by double ELISA and Western blot, who underwent serology testing for both HBsAg and anti-HCV as part of their baseline tests were included in the study, irrespective of their liver condition. Paediatric patients were excluded.

\section{Ethics}

The study was reviewed and approved by the Health Research and Ethics Committee of the UNTH with reference number NHREC/05/01/2008B-FWA000024581RB00002323. Informed consent was obtained from the medical records department of the HIV clinic to access the patients' laboratory results and basic demographic data.

\section{Data collection}

The HIV-positive patients' medical and laboratory records were reviewed to obtain demographic data (age and sex), hepatitis B surface antigen ( $\mathrm{HBsAg}$ ), antibodies to HCV (anti-HCV), and CD4 T-lymphocyte count test results. Serological tests had been performed to determine HIV, HBsAg and anti-HCV status at baseline. HIV screening was done using Alere Determine ${ }^{\mathrm{TM}} \mathrm{HIV}$ $1 / 2$ (Abbott, USA) and Uni-gold ${ }^{\mathrm{TM}}$ (Trinity Biotech Plc, Ireland) as a counter-check when positive HIV results were obtained. Confirmation was with Western blot 
testing (Bio-rad Laboratories Inc, USA). CD4 T-lym-

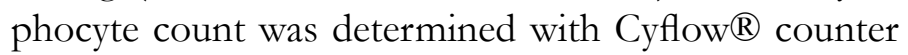
(Sysmex Partec, Germany). As per the national HIV guidelines ${ }^{18}$, all confirmed HIV positive individuals had their HBV and HCV status determined using hepatitis B surface antigen enzyme linked immunosorbent assay (ELISA) (Bio-rad Laboratories Inc., USA) and anti-HCV ELISA (Bio-rad Laboratories Inc., USA) respectively. These methods were consistently used throughout the study period.

Nucleic acid testing for HBV DNA and HCV RNA to confirm positive serological $\mathrm{HBsAg}$ and anti-HCV test results respectively were not available in our laboratory at the time of analyses.

\section{Data analysis}

Data obtained was analyzed with Statistical Package for Social Sciences (SPSS) version 20 (IBM computers, USA) and presented as mean and standard deviation where parametric, or as median and interquartile range where non-parametric. Prevalence was determined by number of positive results over total number of patients tested. Chi-square test was used to compare two categorical data and $\mathrm{p}$-value of $<0.05$ was considered to be statistically significant.

\section{Results}

A total of $4663 \mathrm{HIV}$ positive patient records were included in the study comprising of 3024 (65\%) females and 1639 (35\%) males with mean (standard deviation) ages of 42 (9.9) years and 48 (9.8) years respectively. The age of the males was significantly higher than that of the females $(p<0.0001)$. The age and sex distribution of the HIV positive patients are shown in Table 1.

Table 1: Age and Sex distribution of HIV positive patients

\begin{tabular}{|lll|}
\hline & Total number $=\mathbf{4 6 6 3}$ & \\
Age group (years) & Females & Males \\
$\leq 20$ & 10 & 3 \\
$21-30$ & 243 & 55 \\
$31-40$ & 1218 & 292 \\
$41-50$ & 991 & 703 \\
$51-60$ & 405 & 431 \\
$61-70$ & 125 & 133 \\
$71-80$ & 28 & 18 \\
$>80$ & 4 & 4 \\
Total & $\mathbf{3 0 2 4}(\mathbf{6 5 \%})$ & $\mathbf{1 6 3 9}(\mathbf{3 5 \%})$ \\
\hline
\end{tabular}

The CD4 T-lymphocyte count was available in 4449 records with minimum and maximum counts of 2 and 5069 cells $/ \mathrm{mm}^{3}$ respectively. The median (interquartile range) CD4 T-lymphocyte count was 291 (350) cells/ $\mathrm{mm}^{3}$ and 227 (311) cells $/ \mathrm{mm} 3$ for females and males respectively $(\mathrm{p}=0.193)$. Distribution of the serology results according to age group and CD4 T-lymphocyte count was shown in Table 2 and 3 respectively. 
Table 2: Distribution of positive serology results according to age group

\begin{tabular}{|llll|}
\hline Age (years) & HIV/HBV + only & HIV/HCV+ only & HIV/HBV/HCV+ \\
$\leq 20$ & 34 & 2 & 0 \\
$21-30$ & 136 & 17 & 3 \\
$31-40$ & 130 & 59 & 7 \\
$41-50$ & 51 & 73 & 12 \\
$51-60$ & 9 & 46 & 4 \\
$61-70$ & 2 & 19 & 1 \\
$71-80$ & 3 & 3 & 0 \\
$>80$ & 0 & 0 & 0 \\
Total & $\mathbf{3 6 5}$ & $\mathbf{2 1 9}$ & $\mathbf{2 7}$ \\
\hline
\end{tabular}

Table 3: Distribution of positive serology results according to CD4 T-lymphocyte count*

\begin{tabular}{|c|c|c|c|}
\hline $\begin{array}{l}\text { CD4 T-lymphocyte } \\
\left.\text { count (cells/mm } / \mathbf{m m}^{3}\right)\end{array}$ & HIV/HBV + only & $\begin{array}{l}\text { HIV/HCV+ } \\
\text { only }\end{array}$ & HIV/HBV/HCV+ \\
\hline$\geq 500$ & 42 & 50 & 2 \\
\hline $200-499$ & 128 & 88 & 8 \\
\hline$<200$ & 169 & 65 & 17 \\
\hline Total & 339 & 203 & 27 \\
\hline
\end{tabular}

*CD4 T-lymphocyte count for $\mathrm{n}=4449$ patients were available.

Pearson correlation of the age of the HIV positive patients versus $\mathrm{HBsAg}$ and anti-HCV results were statistically significant $\mathrm{p}=0.000$ and $\mathrm{p}=0.024$ respectively. Also, correlation between their sex versus HBsAg and
anti-HCV results were statistically significant at $\mathrm{p}=0.010$ and $\mathrm{p}=0.003$ respectively. But there was no statistically significant relationship between CD4 T-lymphocyte count and HBsAg or anti-HCV ( $p=1.000$ for both).

Table 4: Prevalence of positive serology results and its sex distribution

\begin{tabular}{|llll|}
\hline & Total $\mathbf{n}=\mathbf{4 6 6 3}$ & Females & Males \\
& No. (\%) & No. (\%) & No. (\%) \\
HIV/HBV+ only & $365(7.8 \%)$ & $199 / 365(55 \%)$ & $166 / 365(45 \%)$ \\
HIV/HCV+ only & $219(4.7 \%)$ & $138 / 219(63 \%)$ & $81 / 219(37 \%)$ \\
HIV/HBV/HCV + & $27(0.58 \%)$ & $11 / 27(41 \%)$ & $16 / 27(59 \%)$ \\
\hline
\end{tabular}


Serology tests results in Table 4 showed: $365 / 4663(7.8 \%)$ tested HBsAg positive (HIV/HBV+ only), 219/4663 (4.7\%) tested anti-HCV positive (HIV/HCV+ only), while both positive results for $\mathrm{HBsAg}$ and anti-HCV
(HIV/HBV/HCV+) were seen in 27/4663 (0.58\%) cases. The relative distribution is displayed in Figure 1, and the sex distribution is shown in Figure 2.

Discussion

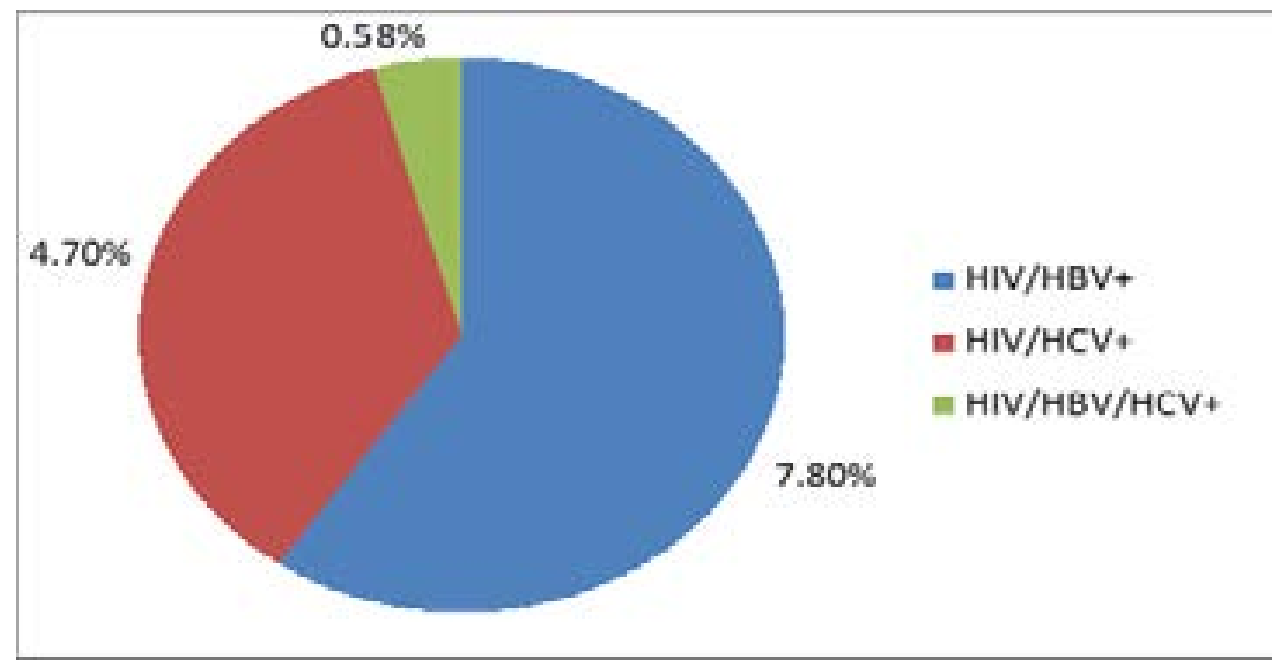

Fig. 1: Distribution of positive serology results among the HIV patients

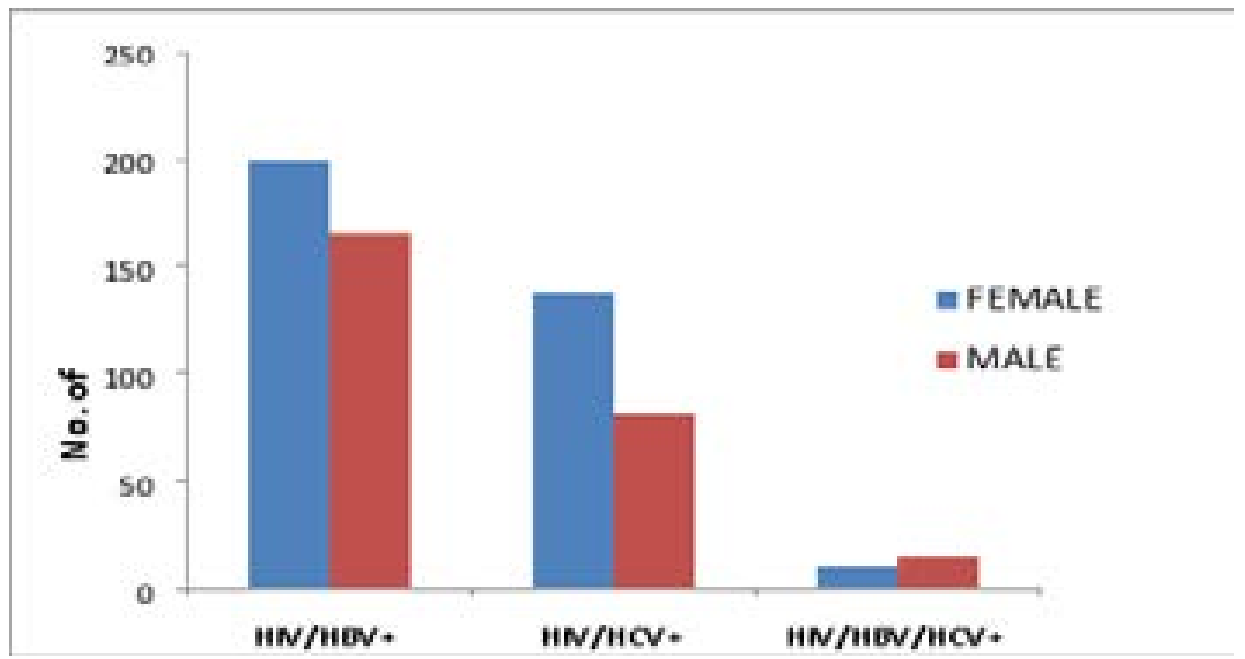

Fig. 2: Sex distribution of positive serology results

This study revealed that $4663 \mathrm{HIV}$ positive adult patients were tested for HBV and HCV co-infection out of the 10,263 new registrations over the same period. This discrepancy may be due to the cost of the tests because our health institution does not offer free testing for HBV and HCV alongside with free HIV testing, similar to other Nigerian settings. ${ }^{19}$ The European AIDS guideline stipulates that all HIV infected patients should be screened for HBV and HCV at diagnosis and then on annual basis.20 However, in low-and medium income countries this may be a challenge. The Nigeria national guideline for HIV prevention, treatment and care recommend only baseline testing for HBsAg and HCV pre-treatment with HAART. ${ }^{18}$

We recorded an $\mathrm{HIV} / \mathrm{HBV}+$ prevalence of $7.8 \%$, which was lower than $11.9 \% \mathrm{HIV} / \mathrm{HBV}$ prevalence documented in a Nigerian study on 1,779 HIV patients 15 , but more than the $1.13 \% \mathrm{HIV} / \mathrm{HBV}+$ prevalence documented in a Burkina Faso study of 11,592 blood donors.21 Other Nigerian studies showed HIV/ $\mathrm{HBV}+$ prevalence ranging from $9.7-25 \%$ but their sample sizes were much smaller than ours. ${ }^{16,17,22}$. A review ar- 
ticle by Askari et al showed that the incidence of HIV/ HBV coinfection was higher in American and European countries, than Asian and African countries, which was probably due to the availability of better diagnostic techniques with lower sensitivities such as nucleic acid testing. ${ }^{23}$ This is buttressed by studies that compared HBV rapid diagnostic test kits versus HBV DNA testing and discovered $11.2 \%$ positive HBV DNA among patient samples that had tested negative to HBsAg rapid test kits. ${ }^{24}$ Appropriate, affordable diagnostics need to be developed for better detection of the hepatitis viruses in order to determine accurate prevalence rates.

Co-infection of $\mathrm{HIV} / \mathrm{HCV}+$ was observed in $4.7 \%$ in this study which is higher than $0.7 \%$ reported by Diwe et al, ${ }^{19}$ and $2.3 \%$ reported by Adewole et al. ${ }^{25}$ This may be due to the higher number of participants in this study as opposed to 404 and 260 respectively in those studies.

We observed that our prevalence of $\mathrm{HIV} / \mathrm{HBV}+(7.8 \%)$ was higher than $\mathrm{HIV} / \mathrm{HCV}+(4.7 \%)$, similar to other studies. ${ }^{19,25}$ This may suggest that although the three viruses have similar routes of transmission; they are not transmitted at the same rate. HIV infection with history of intravenous drug use or multiple transfusions have been consistently found to be the most important risk factor for HCV coinfection, while sexual transmission of HCV is relatively inefficient. ${ }^{26}$ Prevalence of HIV/ HBV is commoner among men who have sex with men, heterosexual persons with multiple sex partners or contact with sex workers among others. ${ }^{27}$

Triple infection $\mathrm{HIV} / \mathrm{HBV} / \mathrm{HCV}+$ was recorded in $0.58 \%$, which was lower than the findings in the study conducted in Abuja city, the capital of Nigeria as $1.5 \% ; 25$ but higher than the findings in a suburban region $0 \%{ }^{19}$ It is uncertain whether city-dwellers are at more risk for contracting these viral infections due to their lifestyle choices.

Knowledge of the HBV/HCV coinfection status is important as choice of treatment varies. HAART regimen for HIV/HBV coinfected patients should include Tenofovir and Emtricitabine as they are active against HIV and HBV and reduces the development of HBV resistance to therapy, while HIV/HCV coinfection requires pegylated interferon- $\alpha$ with Ribavirin, or Direct Acting Antiviral (DAA) therapy e.g. Sofosbuvir.[18] Also, HBV vaccine can be administered in HIV infected adults without serologic evidence of past or present hepatitis B infection. ${ }^{18}$
We observed that most $\mathrm{HIV} / \mathrm{HBV}+$ and triple coinfected patients had the lowest CD4 T-lymphocyte counts of less than 200 cells $/ \mathrm{mm}^{3}$. Another study showed most $\mathrm{HIV} / \mathrm{HBV}+$ patients had CD4 counts of 200-499cells/mm3.28 This may support the theory that coinfection worsens the immune status leading to poorer outcomes. Individuals with CD4 cell count of less than 200 cells $/ \mathrm{mm} 3$ have a 16.2 times higher risk of liver-related deaths than those with a CD4 count of greater than 350 cells $/ \mathrm{mm} 3{ }^{29}$

Although we documented no statistically significant relationship between with CD4 T-lymphocyte count and the hepatitis viruses ( $\mathrm{p}>0.05)$, Opaleye $\mathrm{OO}$ et al, who reported a median CD4 T-lymphocyte count of 142cells $/ \mathrm{mm} 3$, found a statistically significant difference between CD4 count and HBsAg of their participants $(\mathrm{n}=158, \mathrm{p}=0.024){ }^{28}$

When comparing coinfection with the hepatitis viruses, we observed more females had coinfection (HIV/ $\mathrm{HBV}+$ or $\mathrm{HIV} / \mathrm{HCV}+$ ), but more males had triple infection (HIV/HBV/HCV + ). This differs from a Nigerian study that reported HIV/HBV+ and HIV/ $\mathrm{HCV}+$ coinfection was commoner among males ${ }^{15}$, and in a Canadian study of $\mathrm{HIV} / \mathrm{HBV}+$ coinfected individuals, they were more likely to be male $(88.1 \%$ versus $71.3 \%, \mathrm{p}<0.001)$ and to have died $(34.3 \%$ versus $17.9 \%$ $\mathrm{p}<0.001) .{ }^{30}$ Sex distribution is important in directing preventive strategies of antiviral prophylaxis among pregnant HIV patients such as administration of Tenofovir to prevent perinatal transmission, ${ }^{13}$ and $\mathrm{HBV}$ vaccination at birth.

In this study, the sex and age group with the largest number of HIV patients were: females 31 - 40 years, and males $41-50$ years. HBV coinfection (HIV/HBV+) was most prevalent among young adults ( $21-30$ years). This differs from findings by Opaleye et al, where HIV / $\mathrm{HBV}+$ coinfection was most prevalent between age 3049 years. 28 On the other hand, HIV/HCV+ and triple infection $\mathrm{HIV} / \mathrm{HBV} / \mathrm{HCV}+$ were most prevalent among our patients aged $41-50$ years. Mabayoje et al reported HIV/HCV was most prevalent among 30-39 years old. ${ }^{31}$ These age distributions have huge economic implications as they constitute the bulk of the nation's workforce, which could slow or reverse growth in the labour supply and worsen dependency ratio, as well as increase health expenditures for HIV-and liver-related illnesses reducing household incomes. ${ }^{32}$ 


\section{Limitations}

Nucleic acid testing for HBV DNA and HCV RNA would have been ideal to confirm positive serological $\mathrm{HBsAg}$ and anti-HCV test results respectively. But this technique is expensive and not readily available in most African laboratories including ours.

The CD4 T-lymphocyte results were unavailable in 214 patient's records probably due to assay failures or reagent stock-outs. This however did not affect our inclusion criteria, nor was the difference significant enough to affect our correlation results.

HIV viral load results were not included in this study because it was not routinely done as one of the baseline tests as per the national HIV guidelines, mostly due to the expensive cost of the test. The emphasis at the time was to use CD4 T-lymphocyte count for HIV stage classification and monitoring of treatment. ${ }^{33}$

The retrospective nature of this study limited the depth of data we could obtain from the patients. For those patients with positive serology results ( $\mathrm{HBsAg}+$ and anti-HCV+), we could not identify predisposing factors among them, and possibly link it to their HIV infection. Although certain modes of transmission are commoner with each viral infection, this is an opportunity for future research work to delineate our transmission patterns.

\section{Conclusion}

Co-infection of $\mathrm{HIV} / \mathrm{HBV}+$ was more prevalent than $\mathrm{HIV} / \mathrm{HCV}+$, although triple infection (HIV/HBV/ $\mathrm{HCV}+)$ was also observed in this study. Routine screening for these viral infections in the HIV population is necessary to enable prescription of appropriate anti-viral medication. Affordable for HBV and HCV need to be optimized and incorporated into current national HIV treatment programs.

\section{Acknowledgements}

We thank the Principal Investigator- Professor Chinwe Chukwuka and all staff of the Anti-retroviral therapy (HIV) clinic at University of Nigeria Teaching Hospital for their support during data collection for this study.

\section{References}

1. World Health Organization. Global health observatory data repository. www.who.int/gho/hiv/epidemic_status/cases_all/en/ Accessed 10th February 2019.

2. Greub G, Ledergerber B, Battegay M, Grob P, Perrin L, Furrer H, et al. Clinical progression, survival and immune recovery during antiretroviral therapy in patients in HIV-1 and hepatitis C coinfection, Swiss HIV cohort study. Lancet. 2000; 356:1800-1805. PubMed.
3. World Health Organization Global Hepatitis report 2017. WHO, Geneva. April, 2017. www.who.int/hepatitis/publications/global-hepatitis-report2017/en/ Accessed 8th November 2019.

4. Matthews PC, Geretti AM, Goulder PJ, Klenerman P. Epidemiology and impact of HIV coinfection with hepatitis B and hepatitis $C$ viruses in sub-Saharan Africa. J Clin Virol. 2014; 61:20-33.

5. Spearman CW, Afihene M, Ally R, Apica B, Awuku Y, Cunha L, et al. Hepatitis B in sub-Saharan Africa: strategies to achieve the 2030 elimination targets. Lancet Gastroenterol Hepatol. 2017; 2:900-909.

6. Kourtis AP, Bulterys M, Hu DJ, Jamieson DJ. HIVHBV co-infection--a global challenge. $N$ Engl J Med. 2012; 366(19):1749-1752.

7. Parboosing R, Paruk I, Lalloo UG. Hepatitis C virus seropositivity in a South African cohort of HIV infected, ARV naïve patients associated with renal insufficiency and increased mortality. J Med Virol. 2008; 80(9):1530-1536.

8. Hamza M, Samaila AA, Yakasai AM, Babasha M, Borodo MM, Habib AG. Prevalence of Hepatitis B and $C$ viruses infection among HIV-infected patients in a tertiary hospital in North-western Nigeria. Niger J Basic Clin Sci. 2013;10:76-81. PubMed.

9. Saravan S, Velu V, Kumarasamy N, Nandakumar S, Muruvel KG, Balakrishnan P, Suniti S, Thyagarajan Sp. Coinfection of hepatitis B and hepatitis $C$ virus in HIV-infected patients in South India. World J Gastroenterol 2007; 13(37):5015-5020.

10. USAIDS. HIV and AIDS estimates 2013. www.unaids.org. Accessed on $16^{\text {th }}$ February 2019.

11. World Health Organization rapid advice: antiretroviral therapy for HIV infection in adults and adolescents. Nov 2009. Geneva

12. Global health sector strategy on viral hepatitis 20162021. www.who.int/hepatitis/strategy2016-2021/ghsshep/en/ Accessed on 8th November 2019.

13. Pan CQ, Duan Z, Dai E, Zhang S, Han G, Wang $\mathrm{Y}$, et al. Tenofovir to prevent hepatitis $\mathrm{B}$ transmission in mothers with high viral load. N Engl J Med. 2016; 374:2324-2334 PubMed .

14. Prevention, care and treatment of viral hepatitis in the African region: framework for action, 2016-2020. WHO regional office for Africa, 2017. https://www. afro.who.int/sites/default/ files/2017-12/HEPATITIS $\% 20$ in $\% 20$ Africa $\% 20$ WHO $\% 20$ African $\% 20$ Region $\% 202016-2020 \% 20$ FINAL $\% 20 \% 2029 \% 20 N_{0}$ FA_ENGLISH_WEB.pdf

15. Otegbayo JA, Taiwo BO, Akingbola TS, Odaibo GN, Adedapo KS, Penugonda S, et al. Prevalence of hepatitis $\mathrm{B}$ and $\mathrm{C}$ seropositivity in a Nigerian cohort 
of HIV-infected patients. Ann Hepatol. 2008; 7(2):152 PubMed -156.

16. Idoko J, Meloni S, Muazu M, Nimzing L, Badung B, Hawkins C, et al. Impact of hepatitis B virus infection on human immunodeficiency virus response to antiretroviral therapy in Nigeria. Clin Infect Dis. 2009; 49(8):1268-1273.

17. Ejele OA, Nwauche CA, Erhabor O. The prevalence of hepatitis B surface antigenaemia in HIV positive patients in the Niger Delta Nigeria. Niger J Med. 2004; 13(2):175-179.

18. National guidelines for HIV prevention, treatment and care. National AIDS and STI's control programme. Federal Ministry of Health, Abuja, Nigeria. 2016. Available at https://aidsfree.usaid.gov Accessed on 10th November 2019.

19. Diwe CK, Okwara EC, Enwere OO, Azike JE, Nwaimo NC. Sero-prevalence of hepatitis B virus and hepatitis $\mathrm{C}$ virus among HIV patients in a suburban university teaching hospital in south-east Nigeria. $P A M J$ 2013; $16: 7$.

20. Alberti A, Clumeck N, Collins S, Gerlich W, Lundgren J, Palu G et al. Short statement of the first European consensus conference on the treatment of chronic hepatitis B and C in HIV infected patients. J. Hepatol 2005; 42:615-624.

21. Tounkara A, Sarro YS, Kristensen S, Dao S, Diallo H, Diarra B, et al. Seroprevalence of HIV/HBV coinfection in Malian blood donrs. J Int Assoc Physicians AIDS Care (Chic). 2009;8(1): 47-51.

22. Uneke CJ, Ogbu O, Inyama PU, Anyanwu GI, Njo$\mathrm{ku} \mathrm{MO}$, Idoko JH. Prevalence of hepatitis-B surface antigen among blood donors and human immunodeficiency virus-infected patients in Jos, Nigeria. Mem Inst Oswaldo Cru\%: 2005; 100(1):13-16.

23. Askari A, Hakimi H, Nasiri BA, Hassanshahi G, Kazemi MA. Prevalence of hepatitis B coinfection among HIV positive patients : Narrative review article. Iranian J Publ Health. 2014;43(6):705-712.

24. Opaleye OO, Oluremi AS, Atiba AB, Adewumi MO,
Mabayoje OV, Donbraye E, et al. Occult hepatitis B virus infection among HIV positive patients in Nigeria. $J$ Trop Med 2014; 2014:796121.

25. Adewole OO, Anteyi E, Ajuwon Z, Wada I, Elegba $\mathrm{F}$, Ahmed $\mathrm{P}$, et al. Hepatitis B and $\mathrm{C}$ virus co-infection in Nigerian patients with HIV infection.J Infect Dev Ctries 2009;3(5): 369-375.

26. Tedaldi EM, Hullsiek KH, Malvestutto CD, Arduino RC, Fisher EJ, Gaglio ER, et al. Prevalence and characteristics of hepatitis $C$ virus coinfection in human immunodeficiency virus clinical trials group: the Terry Beirn community programs for clinical research on AIDS. Clin Infect Dis 2003; 36:1313-1317.

27. Alter MJ. Epidemiology of viral hepatitis and HIV co-infection. J. Hepatol 2006; 44:86-89.

28. Opaleye OO, Oluremi AS, Ogbolu DO, Babalola BA, Shittu T, AdesiyanAA. Prevalence of hepatitis$B$ virus infection among HIV patients in Ikole Ekiti, South -Western, Nigeria. Asian Pac. J. Health Sci., 2014; 1(4): 507-511.

29. Falade-Nwulia O, Seaberg EC, Rinaldo CR, Badri $\mathrm{S}$, Witt M, Thio CL. Comparative risk of liver-related mortality from chronic hepatitis B versus chronic hepatitis C virus infection. Clin Infect Dis. 2012; 55:507-513 PubMed.

30. Pittman C, Plitt S, Birse T, Doucette K, Romanowski B, Cooper R, et al. Can J Infect Dis Med Microbiol 2014; 25(1): e8-e13.

31. Mabayoje VO, Muhibi MA, Akindele RA, Akinleye CA, Mabayoje PS, Babatunde OS. Hepatitis C virus coinfection among people living with HIV/AIDS in a Nigerian teaching hospital. HIV \& AIDS Review 2013; 12:102-105.

32. Adedigba MA, Naidoo S, Abegunde A, Olagundoye O, Adejuyigbe E, Fakande I. The economic burden of HIV and AIDS on households in Nigeria. Afr J AIDS Res. 2009; 8(1):107-114.

33. 1993 revised classification system for HIV infection and expanded surveillance case definition for AIDS among adolescents and adults. MMWR Recomm Rep. 1992; 41(RR-17):1-19. 